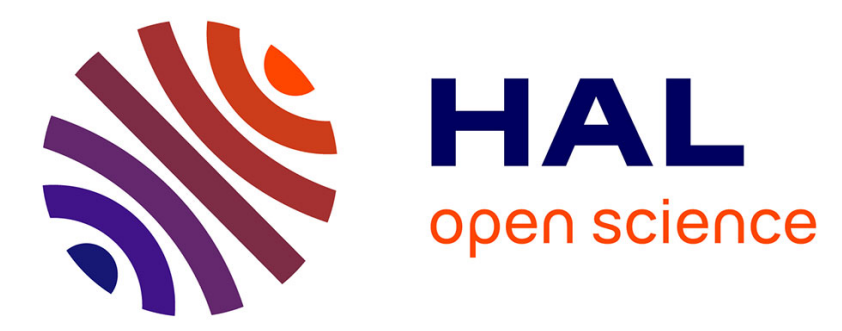

\title{
Acquired mutations during progression of colorectal cancer metastases: possible implications for therapy and prognosis
}

\author{
Mohamed Bouchahda, Abdoulaye Karaboué, Raphaël Saffroy, Pasquale \\ Innominato, Lee Gorden, Catherine Guettier, René Adam, Francis Lévi
}

\section{To cite this version:}

Mohamed Bouchahda, Abdoulaye Karaboué, Raphaël Saffroy, Pasquale Innominato, Lee Gorden, et al.. Acquired mutations during progression of colorectal cancer metastases: possible implications for therapy and prognosis. Cancer Chemotherapy and Pharmacology, 2010, 66 (3), pp.605-609. 10.1007/s00280-010-1298-9 . hal-00582598

\section{HAL Id: hal-00582598 https://hal.science/hal-00582598}

Submitted on 2 Apr 2011

HAL is a multi-disciplinary open access archive for the deposit and dissemination of scientific research documents, whether they are published or not. The documents may come from teaching and research institutions in France or abroad, or from public or private research centers.
L'archive ouverte pluridisciplinaire HAL, est destinée au dépôt et à la diffusion de documents scientifiques de niveau recherche, publiés ou non, émanant des établissements d'enseignement et de recherche français ou étrangers, des laboratoires publics ou privés. 


\title{
Acquired KRAS mutations during progression of colorectal cancer metastases: possible implications for therapy and prognosis
}

\author{
Mohamed Bouchahda $\cdot$ Abdoulaye Karaboué • \\ Raphaël Saffroy · Pasquale Innominato • Lee Gorden • \\ Catherine Guettier · René Adam · Francis Lévi
}

Received: 26 October 2009 / Accepted: 18 February 2010 / Published online: 2 April 2010

(C) Springer-Verlag 2010

\begin{abstract}
Purpose Documentation of a wild-type (wt) KRAS gene in tumor has become mandatory for the prescription of antiEGFR monoclonal antibodies in patients with colorectal cancer (CRC). Acquired KRAS mutations have seldom been reported in metastases from wt KRAS primary CRC. We report the first case of multiple KRAS mutations acquired
\end{abstract}

M. Bouchahda $\cdot$ A. Karaboué $\cdot$ P. Innominato $\cdot$ F. Lévi Chronotherapy Unit and Department of Medical Oncology, Assistance Publique-Hôpitaux de Paris, Villejuif, France

M. Bouchahda · A. Karaboué · P. Innominato · R. Adam · F. Lévi INSERM, U776 "Biological Rhythms and Cancers",

Villejuif, France

M. Bouchahda $\cdot$ A. Karaboué $\cdot$ R. Saffroy $\cdot$ P. Innominato ·

C. Guettier · R. Adam · F. Lévi

Univ Paris Sud 11, Hôpital Paul Brousse,

94800 Villejuif, France

R. Saffroy

Department of Biochemistry,

Assistance Publique-Hôpitaux de Paris, Villejuif, France

L. Gorden $\cdot$ R. Adam

Department of Hepatobiliary Surgery,

Assistance Publique-Hôpitaux de Paris, Villejuif, France

L. Gorden

Department of Surgery and Cancer Biology,

Vanderbilt University Medical Center, Nashville, TN, USA

C. Guettier

Department of Pathology,

Assistance Publique-Hôpitaux de Paris, Villejuif, France

M. Bouchahda $(\square)$

Service d'Oncologie Médicale, Hôpital Paul Brousse,

12 avenue Paul Vaillant Couturier, 94800 Villejuif, France

e-mail: mohamed.bouchahda@pbr.aphp.fr during the metastatic phase of $\mathrm{CRC}$, and retrospectively reviewed all patients with $\mathrm{CRC}$, in whom $K R A S$ was analyzed in at least two tumor samples from distinct lesions.

Methods Genomic DNA purified from paraffin-embedded tissues was used after histological quantification of tumor tissue. The seven KRAS mutations located within codons 12 and 13 were screened using the allelic discrimination assay. Results A 35-year-old woman with CRC liver metastasis, resistant to all conventional cytotoxic agents, experienced for the first time significant tumor shrinkage while cetuximab was added, allowing hepatic resection. Further liver relapse occurred on cetuximab, but a new hepatic resection was attempted. No mutation in KRAS was detected in the primary colon tumor or in synchronous liver metastases. In contrast, in metachronous liver metastasis samples, two distinct mutations at codon 13 and 12 were detected. No acquired mutations were found in all the other 12 CRC cases with at least two serially performed $K R A S$ analyses.

Conclusions Our findings suggest that late switch in KRAS mutational status could occur more frequently than currently recognized and account for acquired resistance to anti-EGFR therapies. Prospective studies are warranted to better estimate the incidence of change in KRAS mutational status and assess their clinical relevance.

Keywords KRAS mutation - Acquired - Metastases · Colorectal cancer

\section{Introduction}

Mutations of the KRAS gene have been recently shown to predict resistance to epidermal growth factor receptor (EGFR)-targeted monoclonal antibodies [1-3]. KRAS wild type $(w t)$ is now a standard requirement for prescription of 
anti-EGFR therapy in patients with metastatic colorectal cancer (mCRC) [4, 5]. Nevertheless, little is known about the evolution of the KRAS mutational status and subsequent gene mutations during the spontaneous course of disease progression and on chemotherapy. In particular, it is unclear whether KRAS mutations are always early events, or could be acquired at later stages of CRC. We report the case of a patient with $\mathrm{mCRC}$, in whom tumor KRAS mutations were acquired after the occurrence of the first metastasis.

\section{Case report}

A 35-year-old-female patient, without personal or familial history of cancer, was diagnosed with adenocarcinoma of the transverse colon and synchronous bulky liver metastases. Immunohistochemistry for MLH1, MSH2 and MSH6 on tumor and healthy liver samples revealed no evidence for hereditary non-polyposis colon cancer (HNPCC). She received 8 cycles of a fluorouracil (5FU) and oxaliplatinbased chronomodulated regimen, which achieved disease stabilization. Irinotecan was added to the regimen for seven cycles, but the patient demonstrated only minor tumor response. A segmental transverse colectomy was then performed, followed by eight cycles of the same triple therapy, but with alternating intravenous (IV) and hepatic arterial infusions (HAI), without any tumor regression. Intravenous cetuximab was therefore added to the previous alternating regimen over 12 additional cycles. This regimen achieved a partial tumor response, associated with grade 2 acneiform rash. The patient could then undergo left hepatectomy and segment VII liver resection. Pathologic examination of the specimen demonstrated viable hepatic metastases with positive surgical margins (R1 resection). Six post-operative cycles of HAI, followed by IV triple therapy associated with IV cetuximab were administered. In spite of continued therapy, new lesions subsequently developed in the liver and the peritoneum. The addition of bevacizumab to the previous regimen did not halt disease progression. Nevertheless, the limited size and number of the progressive lesions prompted a segment $\mathrm{V}$ hepatectomy and the resection of both peritoneal nodules. This surgical procedure achieved complete clearance of all macroscopic disease 11 months after the first hepatectomy. The patient received eight post-operative cycles of IV cetuximab and irinotecan/ 5FU for an additional 6 months with no evidence of disease. Two months after chemotherapy discontinuation, new hepatic and peritoneal lesions were discovered. The patient received various palliative irinotecan, fluoropyrimidine, oxaliplatin, cetuximab, bevacizumab-based regimens resulting at best in stable disease, and finally was lost to follow-up in a clinical setting of tumor progression and general status deterioration in July 2008.

\section{Methods}

A retrospective analysis of the KRAS mutational status was performed on tissues obtained from the primary tumor and subsequently resected liver metastases. Genomic DNA purified from paraffin-embedded tissues was used after histological quantification of tumor tissue in each tumor sample by hematoxylin-eosin-saffron (HES) coloration. The percentage of viable tumor in all the samples analyzed for $K R A S$ mutation varied from 30 to $55 \%$ (Table 1 ). The seven KRAS mutations located within codons 12 and 13 were screened using an allelic discrimination assay using primers and specific probes for each mutated and non-mutated allele as previously described [6]. Briefly, reactions were performed in $15 \mu \mathrm{l}$ comprising $20 \mathrm{ng}$ of DNA, $1 \times$ of specific primers and probes, and $1 \times$ Taqman Genotyping Master Mix (Applied Biosystems, Foster City, CA). DNA was then submitted to PCR cycle conditions on, and analyzed with a Lightcycler 480 instrument (Roche Applied Science, Mannheim, Germany). The analysis of each sample was performed in duplicate, and DNA from wild-type sample and cell lines exhibiting each KRAS mutations were used as controls in each experiment. The detection threshold of our technique was tested using dilution of DNA bearing the various KRAS mutation into normal DNA using the same methods as for patient samples. All mutations were detectable
Table 1 Case report: KRAS mutational status in primary tumor and liver metastases

\begin{tabular}{llll}
\hline $\begin{array}{l}\text { Type and date of } \\
\text { surgery }\end{array}$ & Sample origin & $\begin{array}{l}\text { Proportion of } \\
\text { tumor cells (\%) }\end{array}$ & $\begin{array}{l}\text { KRAS } \\
\text { status }\end{array}$ \\
\hline $\begin{array}{l}\text { Segmental colectomy } \\
\text { OCT, 2004 }\end{array}$ & Primary colon & 40 & $w t$ \\
First hepatectomy & Synchronous liver metastasis (lesion \# 1) & 30 & \\
AUG 2005 & Synchronous liver metastasis (lesion \# 2) & 55 & $w t$ \\
Second hepatectomy & Metachronous liver metastasis (lesion \# 3) & 50 & $w t$ \\
JUL 2006 & Metachronous liver metastasis (lesion \# 4) & 40 & Mutated \\
& & & G38A/G13D \\
& & & Gutated \\
& & G38A/G12D
\end{tabular}


Fig. 1 Mutation analysis of the KRAS gene in the reported patient. Amplification curves using allelic discrimination assay are shown for the primary colon tumor sample (a), one synchronous liver metastasis (b) and two metachronous liver metastatic nodules from the second hepatectomy (c and d). First, second and third rows correspond to the amplification curves obtained with the wild-type, G12D and G13D specific probes, respectively

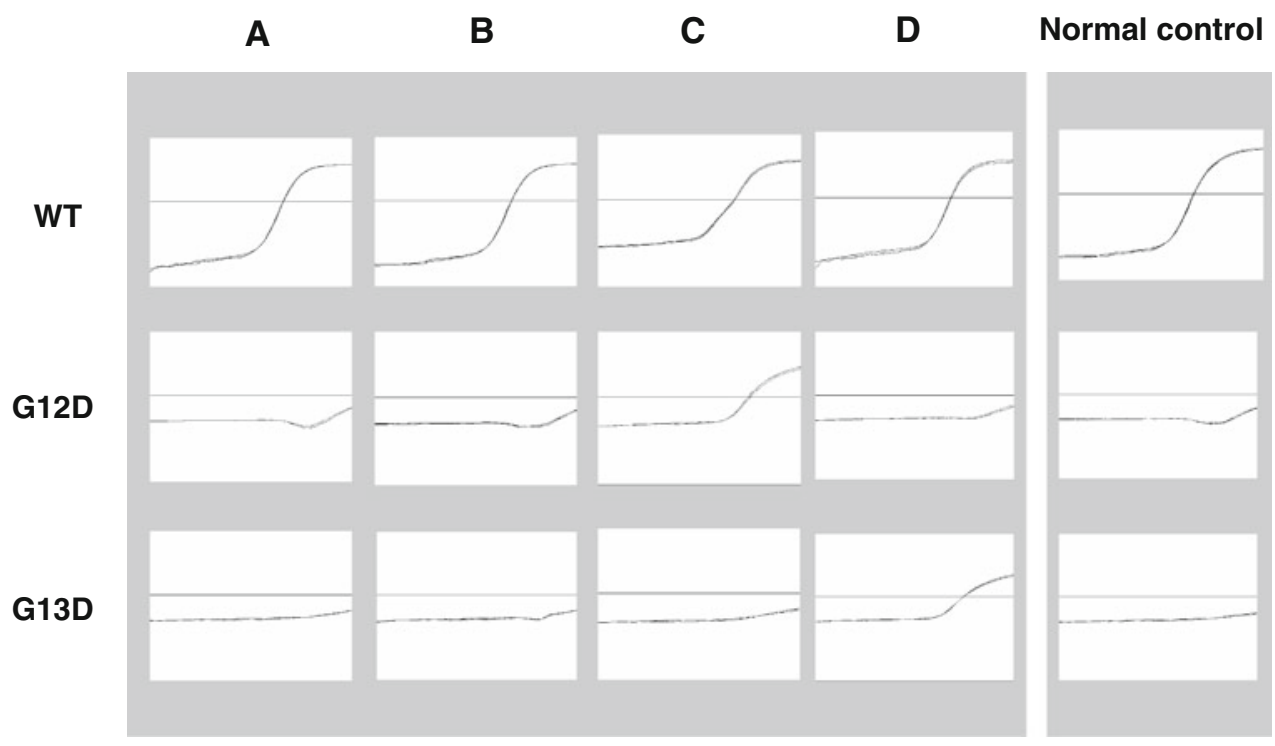

up to dilution of $1 \%$, except G12V up to $5 \%$ and G12S up to $10 \%$. Each sample analysis was performed in duplicate, and wild-type and mutated KRAS controls using DNA extracted from cell lines with known KRAS mutational status were used in each experiment. As shown in Table 1 and Fig. 1, no mutation in $K R A S$ was detected in the primary colon tumor or in synchronous liver metastasis samples. In contrast, in the metachronous liver metastasis from the second hepatectomy, mutations at codon 13 and 12 were detected in two separate nodules.

We then retrospectively reviewed all other patients with CRC, in whom KRAS was analyzed, using the same technique, in at least two tumor samples from distinct lesions. Thirty-three separate analyses were retrieved from 25 tumor sites in 12 patients (Table 2). A KRAS mutation was found in eight of nine tumor sites collected in four patients. Three patients with mutated tumor had the same codon 12 mutation in all collected samples (Table 2; \# 1-3). One patient with a bifocal primary colon tumor had a mutation at codon 13 in only one of them, no mutation in a synchronous liver metastasis and the same mutation in one of two specimens of a subsequent locoregional relapse (Table 2; \# 4). No acquired mutations were detected in any other patient, beside the current case report. However, only 5 of the 12 patients had KRAS analyzed in metastatic or locoregional recurrences occurring sequentially during disease history, comparable to our case report.

\section{Discussion}

Cancer progression is characterized by genomic instability and accumulation of somatic mutations. It is therefore not surprising to observe the development of new mutations during the course of metastatic spread. Nevertheless, KRAS mutations were initially reported as very early events in colorectal carcinogenesis. Even before malignant transformation, about $30-35 \%$ of benign colorectal adenomas bear a KRAS mutation, a proportion similar to that observed in invasive cancer [7, 8]. A similar KRAS mutational status was found both in primary tumor and in metastases for more than $90 \%$ of the patients with CRC [9-12] or lung cancer [13, 14]. This finding is consistent with KRAS mutations mostly occurring as an early molecular event. However, both studies also document a few cases of KRAS mutations in metastases arising from wt KRAS primary tumors. To the best of our knowledge, we report for the first time a change in KRAS mutational status in two sequential samples of metastatic lesions in the same organ during the course of disease progression.

Evolution of KRAS mutations in this setting might be secondary to clonal selection of cells with early mutated $K R A S$ in a given tumor under pressure from anti-EGFR therapy. This selection would render a previously cetuximab sensitive tumor unresponsive. Alternatively, a novel spontaneous mutation in cancer cells could explain the finding of KRAS mutations in metastases, where previously none existed. It is unknown whether exposure to cytotoxic chemotherapy favors KRAS mutation. Neither is it known whether acquired KRAS mutations are observed more frequently in patients with germ-line deficit in DNA repair systems, such as HNPCC patients. In our patient with an early CRC onset, HNPCC was ruled out, yet no other DNA repair deficiency was sought.

The methodology in this report utilizes a widely accepted technique $[5,6]$. The proportion of tumor tissue was appropriate for the technique used to detect gene mutations $[4,5]$ in our case report (Table 1), while, among the 
Table 2 KRAS mutational status in 12 other patients with $\mathrm{mCRC}$ and KRAS analysis in tumor samples collected sequentially

\begin{tabular}{|c|c|c|c|c|c|c|c|}
\hline $\mathrm{Nb}$ & Gender & Primary & Biopsy sites & $\begin{array}{l}\text { Interval between } \\
\text { biopsies (months) }\end{array}$ & $\begin{array}{l}\text { Occurrence } \\
\text { of lesions }\end{array}$ & $\begin{array}{l}\% \text { tumor tissue in the } \\
\text { analyzed sample }\end{array}$ & $\begin{array}{l}\text { Mutation } \\
\text { type }\end{array}$ \\
\hline 1 & M & Rectum & $\begin{array}{l}\text { Primary } \\
\text { Liver metachronous }\end{array}$ & 10 & Sequential & $\begin{array}{l}25 \\
40\end{array}$ & $\begin{array}{l}\text { G12D } \\
\text { G12D }\end{array}$ \\
\hline 2 & M & Rectum & $\begin{array}{l}\text { Liver metachronous } \\
\text { Liver metachronous }\end{array}$ & 2.5 & Simultaneous & $\begin{array}{l}70 \\
20\end{array}$ & $\begin{array}{l}\text { G12C } \\
\text { G12C }\end{array}$ \\
\hline 3 & M & Rectum & $\begin{array}{l}\text { Liver synchronous } \\
\text { Liver synchronous } \\
\text { Liver synchronous }\end{array}$ & $2.5-4.5$ & Simultaneous & $\begin{array}{l}15 \\
20 \\
50\end{array}$ & $\begin{array}{l}\text { G12D } \\
\text { G12D } \\
\text { G12D }\end{array}$ \\
\hline 4 & $\mathrm{~F}$ & $\begin{array}{l}\text { Sigma and } \\
\text { right colon } \\
\text { (bifocal) }\end{array}$ & $\begin{array}{l}\text { Liver synchronous } \\
\text { Primary (right colon) }\end{array}$ & 4 & Simultaneous & $\begin{array}{l}20 \\
40\end{array}$ & $\begin{array}{l}\text { wt } \\
\text { G13D }\end{array}$ \\
\hline 5 & M & Left colon & $\begin{array}{l}\text { Liver synchronous } \\
\text { Liver metachronous }\end{array}$ & 24 & Sequential & $\begin{array}{l}40 \\
55\end{array}$ & $\begin{array}{l}\text { wt } \\
\text { wt }\end{array}$ \\
\hline 6 & M & Sigma colon & $\begin{array}{l}\text { Primary } \\
\text { Pelvic recurrence }\end{array}$ & 33 & Sequential & $\begin{array}{l}60 \\
10-40\end{array}$ & $\begin{array}{l}\text { wt } \\
\text { wt }\end{array}$ \\
\hline 7 & M & Lower rectum & $\begin{array}{l}\text { Liver metachronous } \\
\text { Liver metachronous }\end{array}$ & 15 & Sequential & $\begin{array}{l}50 \\
40\end{array}$ & $\begin{array}{l}\text { wt } \\
\text { wt }\end{array}$ \\
\hline 8 & M & Sigma colon & $\begin{array}{l}\text { Liver metachronous } \\
\text { Lymphadenopathy }\end{array}$ & 28 & Sequential & $\begin{array}{l}35 \\
40\end{array}$ & $\begin{array}{l}\text { wt } \\
\text { wt }\end{array}$ \\
\hline 9 & M & Sigma colon & $\begin{array}{l}\text { Liver synchronous } \\
\text { Liver synchronous }\end{array}$ & 11 & Simultaneous & $\begin{array}{l}15 \\
60\end{array}$ & $\begin{array}{l}\text { wt } \\
\text { wt }\end{array}$ \\
\hline 10 & M & Sigma colon & $\begin{array}{l}\text { Lung metachronous } \\
\text { Lung metachronous }\end{array}$ & 3 & Simultaneous & 50 & $\begin{array}{l}\text { wt } \\
\text { wt }\end{array}$ \\
\hline 11 & M & Left colon & $\begin{array}{l}\text { Liver synchronous } \\
\text { Liver synchronous }\end{array}$ & 4 & Simultaneous & $\begin{array}{l}20 \\
90\end{array}$ & $\begin{array}{l}\text { wt } \\
\text { wt }\end{array}$ \\
\hline 12 & M & Right colon & $\begin{array}{l}\text { Primary } \\
\text { Liver synchronous }\end{array}$ & 4 & Simultaneous & Not available & $\begin{array}{l}\text { wt } \\
\text { wt }\end{array}$ \\
\hline
\end{tabular}

other cases tested, some negative samples had an unknown or insufficient percentage of tumor cells and may be unreliable (Table 2, \# 6, 9, 12). Furthermore, the sensitivity of our test, measured by a DNA dilution technique, was even higher than that (20\%) reported by Lievre et al. [6]. This finding may be due to technical differences introduced when adapting the method to our local specificity. In particular, PCR master mix and PCR instrument were different than those described in the original publication [6]. Furthermore, all specimens were independently tested in duplicate. It is therefore unlikely that the finding of a late KRAS mutation would be explained by a false negative result in the samples from the primary tumor and the first hepatectomy. In addition, the clinical course of this patient is consistent with the late change in KRAS status. Albeit heavily exposed to all active drugs used to treat mCRC, only the initial introduction of cetuximab resulted in clinically relevant tumor shrinkage, while the tumor was harboring a wt KRAS gene. Subsequently, the tumor progressed on cetuximab therapy, and tumor tissue from the second hepatectomy showed a mutated KRAS gene. Of note, two different mutations were detected in two separate histological samples, suggesting multiple mutations, or secondary selection of multiple cetuximab-resistant clones during cetuximab therapy.
Intraneoplastic heterogeneity of cancer populations is a well-known phenomenon that could determine the genesis of potential drug-resistant metastatic clones [15-19] Similarly, tumor heterogeneity is a limit of tumor biomarker analyses [20], illustrated in our case by the presence of two distinct mutations in two nodules sampled during the same metastatic phase. The lack of KRAS mutations in the initial samples could have been due to sampling in a nonmutated area of the tumor [19]. It is likely that increasing the number of samples analyzed in one tumor location would increase the incidence of discrepant KRAS status. The limits of the conventional technique using DNA extracted from formalin-fixed tumor samples could be also improved by more sensitive techniques and other DNA source [21].

Finally, assessment of KRAS status for therapeutic purposes represents a new paradigm in cancer therapy. Our findings suggest that a late switch in KRAS mutational status could occur more frequently than currently recognized and account for acquired resistance to anti-EGFR therapies. Progressive metastases unresponsive to treatment do not benefit from metastasis resection [22] and are usually not resected. KRAS analysis is therefore not available at the time of progression. In this respect, our patient was an 
exception as she was operated despite tumor progression, due to limited tumor location and size. Of note, wt KRAS metastases can be seen despite mutated KRAS in primary tumors and vice versa $[9,10]$. This observation could justify serial assessments of KRAS mutations during the course of CRC in order to adjust therapeutic decisions and treatment strategies, especially in patients with tumor initially bearing wt KRAS. Prospective studies will be necessary to better estimate the incidence of change in KRAS mutational status through the course of metastatic disease and assess their clinical relevance.

\section{References}

1. Linardou H, Dahabreh IJ, Kanaloupiti D et al (2008) Assessment of somatic k-RAS mutations as a mechanism associated with resistance to EGFR-targeted agents: a systematic review and metaanalysis of studies in advanced non-small-cell lung cancer and metastatic colorectal cancer. Lancet Oncol 9:962-997

2. Milano G, Etienne-Grimaldi MC, Dahan L et al (2008) Epidermal growth factor receptor (EGFR) status and K-Ras mutations in colorectal cancer. Ann Oncol 19:2033-2038

3. Cappuzzo F, Varella-Garcia M, Finocchiaro G et al (2008) Primary resistance to cetuximab therapy in EGFR FISH-positive colorectal cancer patients. Br J Cancer 99:83-89

4. American Society of Clinical Oncology provisional clinical opinion (2009) Testing for KRAS gene mutations in patients with metastatic colorectal carcinoma to predict response to anti-epidermal growth factor receptor monoclonal antibody therapy. J Clin Oncol 27:2091-2096

5. Jimeno A, Messersmith WA, Hirsch FR, Franklin WA, Eckhardt SG (2009) KRAS mutations and sensitivity to epidermal growth factor receptor inhibitors in colorectal cancer: practical application of patient selection. J Clin Oncol 27:1130-1136

6. Lièvre $\mathrm{A}$, Bachet JB, Boige $\mathrm{V}$ et al (2008) KRAS mutations as an independent prognostic factor in patients with advanced colorectal cancer treated with cetuximab. J Clin Oncol 26:374-379

7. Yang S, Farraye FA, Mack C, Posnik O, O’Brien MJ (2004) BRAF and KRAS mutations in hyperplastic polyps and serrated adenomas of the colorectum: relationship to histology and $\mathrm{CpG}$ island methylation status. Am J Surg Pathol 28:1452-1459

8. Velho S, Moutinho C, Cirnes L et al (2008) BRAF, KRAS and PIK3CA mutations in colorectal serrated polyps and cancer: primary or secondary genetic events in colorectal carcinogenesis? BMC Cancer 8:255

9. Artale S, Sartore-Bianchi A, Veronese SM et al (2008) Mutations of KRAS and BRAF in primary and matched metastatic sites of colorectal cancer. J Clin Oncol 26:4217-4219

10. Molinari F, Martin V, Saletti P et al (2009) Differing deregulation of EGFR and downstream proteins in primary colorectal cancer and related metastatic sites may be clinically relevant. Br J Cancer 100:1087-1094

11. Loupakis F, Pollina L, Stasi I et al (2009) PTEN expression and KRAS mutations on primary tumors and metastases in the prediction of benefit from cetuximab plus irinotecan for patients with metastatic colorectal cancer. J Clin Oncol 27:2622-2629

12. Santini D, Loupakis F, Vincenzi B et al (2008) High concordance of KRAS status between primary colorectal tumors and related metastatic sites: implications for clinical practice. Oncologist 13:1270-1275

13. Badalian G, Barbai T, Rásó E, Derecskei K, Szendrôi M, Tímár J (2007) Phenotype of bone metastases of non-small cell lung cancer: epidermal growth factor receptor expression and K-RAS mutational status. Pathol Oncol Res 13:99-104

14. Kalikaki A, Koutsopoulos A, Trypaki M et al (2008) Comparison of EGFR and K-RAS gene status between primary tumours and corresponding metastases in NSCLC. Br J Cancer 99:923-929

15. Dexter DL, Leith JT (1986) Tumor heterogeneity and drug resistance. J Clin Oncol 4:244-257

16. Sweeney C, Boucher KM, Samowitz WS et al (2009) Oncogenetic tree model of somatic mutations and DNA methylation in colon tumors. Genes Chromosomes Cancer 48:1-9

17. Kimura K, Nagasaka T, Hoshizima N et al (2007) No duplicate $\mathrm{K}$-RAS mutation is identified on the same allele in gastric or colorectal cancer cells with multiple K-RAS mutations. J Int Med Res 35:450-457

18. Losi L, Baisse B, Bouzourene H, Benhattar J (2005) Evolution of intratumoral genetic heterogeneity during colorectal cancer progression. Carcinogenesis 26:916-922

19. Baisse B, Bouzourene H, Saraga EP, Bosman FT, Benhattar J (2001) Intratumor genetic heterogeneity in advanced human colorectal adenocarcinoma. Int J Cancer 93:346-352

20. Pintilie M, Iakovlev V, Fyles A, Hedley D, Milosevic M, Hill RP (2009) Heterogeneity and power in clinical biomarker studies. J Clin Oncol 27:1517-1521

21. Holdhoff M, Schmidt K, Donehower R, Diaz LA Jr (2009) Analysis of circulating tumor DNA to confirm somatic KRAS mutations. J Natl Cancer Inst 101:1284-1285

22. Adam R, Pascal G, Castaing D et al (2004) Tumor progression while on chemotherapy: a contraindication to liver resection for multiple colorectal metastases? Ann Surg 240:1052-1061 